\title{
DISPARITAS GENDER DALAM PEMBANGUNAN PARIWISATA RAMAH LINGKUNGAN (Gender Disparities in Ecologically Friendly-Tourism Development)
}

\author{
Ismi Dwi Astuti Nurhaeni, Rara Sugiarti, Sri Marwanti, Ryza D. Pratiwi \\ Universitas Sebelas Maret \\ Email: ismidwiastuti@staff.uns.ac.id
}

\begin{abstract}
ABSTRAK
Artikel ini menganalisis disparitas gender dalam pembangunan pariwisata ramah lingkungan, mencakup keterlibatan, kompetensi, hambatan internal dan eksternal perempuan dan laki-laki. Data dikumpulkan dengan survey terhadap 400 responden perempuan dan laki-laki serta diskusi kelompok terfokus terhadap 18 informan. Analisis data menggunakan analisis disparitas gender pada tahap perencanaan, implementasi, monitoring dan evaluasi. Hasil penelitian menemukan adanya disparitas gender dalam pembangunan pariwisata ramah lingkungan, dimana perempuan cenderung masih termarginalkan, baik dalam hal keterlibatan, kompetensi, hambatan internal maupun hambatan eksternal. Disparitas gender tertinggi dalam keterlibatan perempuan dan laki-laki pada pembangunan pariwisata ramah lingkungan terjadi pada tahap implementasi. Kompetensi perempuan lebih rendah dibandingkan laki-laki dan hambatan internal serta eksternal perempuan lebih tinggi dibandingkan laki-laki. Rekomendasi penelitian adalah perlunya percepatan pengarusutamaan gender dalam pembangunan pariwisata ramah lingkungan melalui alokasi anggaran responsif gender dengan perhatian utama mengatasi stereotip gender dan peningkatan kapasitas sumber daya manusia.
\end{abstract}

Kata Kunci:Disparitas gender, pembangunan pariwisata, ramah lingkungan. 
Disparitas Gender Dalam Pembangunan Pariwisata ...

\section{ABSTRACT}

This article explores gender disparities in ecologically friendly-tourism development, including the involvement, competence, internal and external barriers of women and men. The data were collected using survey on 400 respondents, consisting of women and men and focus group discussion with 18 informants. The data analysis uses analysis of gender disparities on planning, implementing, monitoring and evaluating the stage of ecologically friendly- tourism development. The finding shows that gender disparities happen in ecologically friendlytourism development, in which women are still marginalized in terms of their involvement, competency, internal and external barriers. The highest gender disparities on the involvement of women and men in ecologically friendly-tourism development occurred in the implementation. Women's competence is lower than that of men, and women's barrier are higher than that of men. Accordingly, gender mainstreaming in developing environmentally-friendly tourism should be empowered through gender based-financial allocation, especially for eliminating gender stereotip and improving human resources capacities in developing environmentally-friendly tourism.

Keywords: Gender disparites, tourism development, ecologically friendly

\section{A. Pendahuluan}

Pembangunan pariwisata berpotensi menyumbang perekonomian daerah serta mendukung perlindungan dan pelestarian lingkungan hidup (Silva \& Khatiwada, 2014; Merce \& Milin, 2014; Kelkit, Celik \& Esbah, 2010). Pada saat yang sama pembangunan pariwisata berpotensi menimbulkan pencemaran dan kerusakan lingkungan (Wearing, Cunningham, Schweinsberg \& Jobberns 2014). Oleh karena itu perlu dikembangkan pembangunan pariwisata ramah lingkungan, yaitu pembangunan pariwisata yang mendasarkan pada prinsipprinsip pembangunan berkelanjutan.

Pariwisata ramah lingkungan sering disebut sebagai pariwisata berwawasan lingkungan hidup, pariwisata hijau, dan pariwisata lestari atau pariwisata berkelanjutan. Farsari \& Prastacos (tt) mengembangkan indikator pariwisata berwawasan lingkungan dengan mendasarkan pada prinsip-prinsip sustainable tourism, yang terdiri atas: (1) Using resource sustainably; (2) Reducing over consumption and waste; (3) Maintaining diversity; (4) Integrating tourism into planning; (5) Supporting local economies; (6) Involving local communities; (7) Consulting stakeholders and the public; (8) Training staff; (9) Marketing tourism 
responsibly; (10) Undertaking research. Pariwisata ramah lingkungan dimaksudkan untuk memelihara harmoni antara elemen-elemen seperti kebutuhan-kebutuhan pengembangan pariwisata, melindungi lingkungan alam, sosial dan budaya, kualitas produk pariwisata, profesionalisme sumber daya manusia, dan juga kepuasan wisata.

Partisipasi masyarakat dan strategi penguatannya di dalam pembangunan pariwisata ramah lingkungan sangatlah penting dilakukan (Ghimire \& Upreti, 2011). Hal ini sejalan dengan Clements (2007) yang menyatakan bahwa partisipasi masyarakat lokal merupakan salah satu dari tiga pilar utama pembangunan pariwisata berkelanjutan. Dua pilar utama lainnya adalah konservasi dan wisata bisnis. Clements menyatakan bahwa implementasi prinsip-prinsip pembangunan pariwisata berkelanjutan akan lebih efektif jika orientasi non ekonomi ditingkatkan dengan mempertimbangkan tiga pilar utama tersebut.

Kesetaraan dan keadilan gender dalam pembangunan pariwisata ramah lingkungan telah dijamin melalui beberapa regulasi. Indonesia mengeluarkan Undang-undang Nomor 7 Tahun 1984 Tentang Ratifikasi Konvensi Penghapusan Segala Bentuk Diskriminasi terhadap Perempuan, Instruksi Presiden Nomor 9 Tahun 2000 Tentang Pengarusutamaan Gender dalam Pembangunan Nasional, Peraturan Presiden Nomor 5 Tahun 2010 Tentang Rencana Pembangunan Jangka Menengah Nasional dan Peraturan Menteri Dalam Negeri Nomor 67 Tahun 2011 yang menyatakan bahwa Pemerintah harus mengembangkan kebijakan pembangunan responsif gender. Namun demikian, hasil penelitian terdahulu menemukan bahwa jenis kelamin, konstruksi sosial budaya dan kebijakan publik seringkali mengabaikan peran perempuan dalam pembangunan pariwisata ramah lingkungan. Akibatnya, kompetensi dan kapasitas perempuan dalam pembangunan pariwisata tidak diperhitungkan dan belum mampu memenuhi prinsip-prinsip pengembangan dan pengelolaan pariwisata ramah lingkungan. Selain pengabaian perempuan dalam pembangunan pariwisata ramah lingkungan, perempuan seringkali menerima dampak yang lebih besar dan kurang menguntungkan dari kerusakan lingkungan (khususnya di Selatan Dunia Ketiga) daripada laki-laki (Mies \& Shiva, 1993 dalam Subono, 2014:168). D'Eabonne (1974) dalam Subono (2014:168) menyatakan adanya hubungan antara opresi terhadap perempuan, dengan opresi terhadap alam. Pemahaman terhadap alam adalah penting untuk mencapai pemahaman yang lebih baik tentang opresi terhadap perempuan dan alam. Karena itu, teori dan praktek feminisme harus memperhitungkan 
Disparitas Gender Dalam Pembangunan Pariwisata ...

perspektif ekologi dan memecahkan masalah-masalah ekologi harus memasukkan perspektif feminisme (Karen, 1997 dalam Subono, 2014: 168; Tong, 1998).

Kajian tentang hubungan antara gender ataupun feminisme dengan lingkungan telah dilakukan. Buckingham (2004) menemukan adanya pengaruh ecofeminism terhadap kebijakan yang berkaitan dengan ketidaksetaraan gender dan lingkungan selama 20 tahun terakhir. Hasil risetnya menemukan adanya pergeseran kebijakan yang substansial di Eropa dan United Kingdom sebagai akibat dari lobi yang dilakukan oleh ecofeminism. Temuan Buckingham menunjukkan bahwa perempuan merupakan aktor penting dalam pembangunan pariwisata. Di Indonesia, studi-studi terkait gender dan lingkungan telah dilakukan oleh Khotimah (2005), Utami (2000), Pamulardi (2006) dan Nugroho (2012). Riset-riset mereka menekankan pada pentingnya institusi manajemen pengembangan pariwisata, pentingnya formulasi strategi pembangunan pariwisata tirta yang ramah lingkungan, pentingnya perencanaan pengembangan agrowisata yang ramah lingkungan berdasarkan tujuh tahapan perencanaan dan pentingnya pelibatan masyarakat untuk mengelola sumber daya alam sebagai daya tarik wisata. Studi-studi ini membantu dalam memahami pembangunan pariwisata, namun belum secara spesifik menjelaskan peran gender dalam pembangunan pariwisata. Karena itu kajian tentang disparitas gender dalam pembangunan pariwisata ramah lingkungan di Indonesia sangat penting.

Kawasan Gunung Lawu di Karanganyar Indonesia memiliki potensi pariwisata berupa alam maupun keragaman budaya, namun kawasan ini juga berpotensi mengalami kerusakan lingkungan sehingga pariwisata harus dikelola dengan baik agar mampu mendukung keberlanjutan sumber daya yang ada sebagai daya tarik wisata. Permasalahannya, keterlibatan perempuan dalam pengembangan pariwisata ramah lingkungan seringkali diabaikan, sehingga kebijakan tersebut belum mampu menyentuh kebutuhan untuk meningkatkan kapasitas perempuan dalam pembangunan pariwisata ramah lingkungan.

Artikel ini mengkaji disparitas gender dalam keterlibatan, kompetensi, hambatan internal dan hambatan eksternal perempuan dan laki-laki pada pembangunan pariwisata ramah lingkungan di kawasan Gunung Lawu Karanganyar Indonesia. Melalui kajian ini akan dapat dikembangkan ilmu pengetahuan yang responsif gender.

Penelitian ini dilaksanakan di kawasan Gunung Lawu Kabupaten Karanganyar Indonesia. Pemilihan lokasi didasarkan atas fakta bahwa kawasan 
tersebut memiliki sejumlah daya tarik wisata alam yang rawan dampak sehingga harus dikelola secara ramah lingkungan. Jenis penelitian ini adalah deskriptif kuantitatif dan kualitatif, yaitu menggambarkan disparitas gender tentang keterlibatan perempuan dibandingkan laki-laki dalam pembangunan pariwisata ramah lingkungan, kompetensi perempuan dibandingkan laki-laki dalam pembangunan pariwisata ramah lingkungan, serta hambatan internal dan eksternal perempuan dibandingkan laki-laki dalam pembangunan pariwisata ramah lingkungan.

Sumber data berupa responden, informan, tempat dan peristiwa serta arsip dan dokumen. Responden ditetapkan sebanyak 400 orang, terdiri atas 200 orang responden laki-laki dan 200 orang responden perempuan yang tersebar di 5 (lima) kecamatan, dengan masing-masing kecamatan 40 orang perempuan dan 40 orang laki-laki. Informan ditetapkan secara purposive, terdiri atas unsur pemerintah (Dinas Kebudayaan dan Pariwisata, Badan Lingkungan Hidup, Badan Pemberdayaan Perempuan, Perlindungan Anak dan Keluarga Berencana), dan Perwakilan Kecamatan. Pengumpulan data dilakukan dengan metode observasi lapangan (site observation), diskusi kelompok terarah (focus group discussion), wawancara mendalam (in-depth interview), dan metode simak (existing document study).

Analisis data penelitian ini menggunakan analisis disparitas gender yang disajikan dengan menggunakan statistik sederhana (analisis persentase) serta didukung dengan analisis kualitatif menggunakan analisis interaktif yang menggarisbawahi hubungan antar tiga komponen utama, yakni reduksi data, sajian data, dan penarikan kesimpulan. Jawaban pertanyaan responden kategori pernah diberi skor " 1 " dan apabila tidak pernah diberi skor "0". Skor jawaban responden kemudian diklasifikasikan ke dalam dua kelompok yaitu "tinggi" dan "rendah". Rentang tinggi dan rendah dihitung berdasarkan rumus (jumlah pertanyaan +1 ) dibagi 2 .

Tabel 1: Aspek yang dianalisis dan kategori

\begin{tabular}{|c|c|c|c|}
\hline \multirow{2}{*}{ No } & \multirow{2}{*}{ Aspek yang dianalisis / indikator } & \multicolumn{2}{|c|}{ Kategori } \\
\hline & & Rendah & Tinggi \\
\hline & \multicolumn{3}{|c|}{ Keterlibatan perempuan dan laki-laki dalam pembangunan pariwisata ramah lingkungan } \\
\hline & Keterlibatan pada Tahap Perencanaan : 8 pertanyaan & Skor $0-4$ & Skor 5- \\
\hline & $\begin{array}{l}\text { (1) eksplorasi potensi pariwisata, (2) pembangunan potensi pariwisata, (3) } \\
\text { pembangunan infra struktur pariwisata, (4) pembangunan atraksi } \\
\text { pariwisata, (5) pembangunan pariwisata ramah lingkungan, (6) sosialisasi } \\
\text { Sapta Pesona Pariwisata, (7) aktif mengekspresikan pendapat pada } \\
\text { pertemuan formal, dan (8) keterlibatan dalam proses pengambilan } \\
\text { keputusan }\end{array}$ & & 8 \\
\hline
\end{tabular}


Disparitas Gender Dalam Pembangunan Pariwisata ...

\section{Keterlibatan pada tahap Implementasi: 29 pertanyaan}

- Pembangunan Fisik: (1) mengkonstruksi infra struktur; mengkonstruksi Gazebo; (3) mengkonstruksi toilet umum; menyediakan tempat pembuaangan sampah; (5) membuat papan pengumuman

- Penyediaan Pelayanan: (6) pelayanan transportasi; (7) pelayanan komunikasi; (8) lodging services; (9) pelayanan makanan; (10) pelayanan kesehatan; (11) menjual tiket masuk; (12) menjual tiket parkir; (13) menjaga parkir; (14) menjual suvenir; (15) menjaga keamanan; (16) curbing trash; (17) mengorganisasi toko dan merchandises; (18) menjadi penjaga toko dan melayani pembeli;

- Aktivitas pengambilan keputusan: (19) berpartisipasi dalam pertemuan evaluasi pelayanan pariwisata; (20) berpartisipasi dalam pertemuan evaluasi keuangan.

- Fungsi Pemeliharaan: (21) controlling merchants; (22) cleaning tourist sites; (23) menjaga keamanan; (24) menjaga pesanan; (25) menjaga kebersihan; (26) menjaga kesejukan; (27) menjaga keindahan; (28) melayanan pariwisata yang menyenangkan; (29) memberi kesan positif.

Keterlibatan dalam Monitoring dan Evaluasi: 3 pertanyaan

Skor $0-2 \quad$ Skor 3

Keterlibatan dalam (1) aktivitas monitoring pariwisata; (2) menilai aktivitas pariwisata untuk peningkatan fasilitas dan pelayanan pariwisata; (3) memberikan saran untuk peningkatan fasilitas dan pelayanan pariwisata.
Skor 0-14 Skor

$15-29$

\begin{tabular}{llll}
\hline Keterlibatan dalam Monitoring dan Evaluasi: 3 pertanyaan & Skor 0-2 & Skor 3 \\
Keterlibatan dalam (1) aktivitas monitoring pariwisata; (2) menilai & & \\
aktivitas pariwisata untuk peningkatan fasilitas dan pelayanan & & \\
pariwisata; (3) memberikan saran untuk peningkatan fasilitas dan \\
pelayanan pariwisata.
\end{tabular}

\section{(3) Hambatan Internal: 8 pertanyaan}

(1) Keterbatasan pengetahuan tentang pariwisata

(2) Keterbatasan pengetahuan tentang lingkungan

(3) Keterbatasan skill dalam bekerja di pariwisata

(4) Rendahnya tingkat pendidikan

(5) Rendahnya antusiasme untuk bekerja di pariwisata

(6) Terbatasnya motivasi untuk bekerja di pariwisata

(7) Terbatasnya kreativitas untuk menangkap peluang kerja dalam pariwisata

(8) Rendahnya pendapatan di sektor pariwisata

(4) Hambatan eksternal: 4 pertanyaan

(1) tidak adanya kebijakan khusus tentang pembangunan pariwisata ramah lingkungan; (2) tidak adanya kebijakan khusus tentang pemberdayaan Score 0-2 Score 3perempuan dalam pembangunan pariwisata ramah lingkungan; (3) langkanya aktivitas perempuan dalam pariwisata; (4) keterbatasan anggaran untuk aktivitas yang berhubungan dengan pemberdayaan perempuan dalam pariwisata. 
Ismi Dwi Astuti Nurhaeni, Rara Sugiarti, Sri Marwanti, Ryza D. Pratiwi

\section{B. Pembahasan}

\section{Disparitas Gender Keterlibatan Perempuan dan Laki-laki}

Keterlibatan perempuan dalam pembangunan pariwisata ramah lingkungan kurang dominan dibandingkan laki-laki, baik pada tahap perencanaan, pelaksanaan, monitoring dan evaluasi. Pada tahap perencanaan, keterlibatan tinggi laki-laki mencapai $21.0 \%$ dan perempuan mencapai $12.0 \%$. Dengan demikian terdapat disparitas gender sebesar $-9.0 \%$. Pada tahap implementasi, keterlibatan tinggi laki-laki mencapai $45.0 \%$ dan perempuan mencapai $31.5 \%$. Dengan demikian terdapat disparitas gender sebesar $-13.5 \%$. Pada tahap monitoring dan evaluasi, keterlibatan tinggi laki-laki mencapai 34.0\% dan perempuan mencapai $26.0 \%$. Dengan demikian terdapat disparitas gender sebesar $-8.0 \%$.

Tabel 2: Keterlibatan Perempuan dan Laki-laki pada Pembangunan Pariwisata Ramah Lingkungan

\begin{tabular}{|c|c|c|c|c|c|c|}
\hline \multirow{2}{*}{ No } & \multirow{2}{*}{ Tahap } & \multicolumn{2}{|c|}{ Laki-laki $(n=200)$} & \multicolumn{2}{|c|}{ Perempuan $(n=200)$} & \multirow{2}{*}{$\begin{array}{c}\text { Disparitas } \\
\text { Gender (pada } \\
\text { keterlibatan } \\
\text { tinggi) } \\
\text { (kolom 5-kolom } \\
\text { 3) }\end{array}$} \\
\hline & & Tinggi & Rendah & Tinggi & Rendah & \\
\hline$(1)$ & $(2)$ & (3) & $(4)$ & (5) & (6) & $(7)$ \\
\hline 1 & Perencanaan & $42(21.0 \%)$ & $158(79.0 \%)$ & $24(12.0 \%)$ & $176(88.0 \%)$ & -9 \\
\hline 2 & Implementasi & $90(45.0 \%)$ & $110(55.0 \%)$ & $63(31.5 \%)$ & $137(68.5 \%)$ & $-13,5$ \\
\hline 3 & $\begin{array}{l}\text { Monitoring \& } \\
\text { Evaluasi }\end{array}$ & $68(34.0 \%)$ & $132(66.0 \%)$ & $52(26.0 \%)$ & $148(74.0 \%)$ & -8 \\
\hline
\end{tabular}

Sumber: data primer

Pada tahap perencanaan pembangunan pariwisata ramah lingkungan, peran perempuan termarginalisasi dalam delapan aspek, yaitu: menggali potensi pariwisata, mengembangkan potensi pariwisata, mengembangkan sarana prasarana (sarpras) pariwisata, mengembangkan atraksi pariwisata, mengembangkan pariwisata ramah lingkungan, sosialisasi Sapta Pesona Pariwisata, aktif mengeluarkan pendapat dalam pertemuan formal, dan ikut dalam proses pengambilan keputusan. Dari ke delapan aspek tersebut, marginalisasi perempuan terlihat sangat jelas, khususnya dalam pengembangan infra struktur, pengembangan atraksi pariwisata, dan keaktifan dalam mengekspresikan pendapat. 
Disparitas Gender Dalam Pembangunan Pariwisata ...

Tabel 3: Tingkat Keterlibatan Tinggi Perempuan dan Laki-laki Pada Tahap Perencanaan

\begin{tabular}{|c|c|c|c|c|c|}
\hline \multirow{2}{*}{ Keterlibatan Tinggi pada tahap Perencanaan } & \multicolumn{2}{|c|}{ Laki-laki } & \multicolumn{2}{|c|}{ Perempuan } & \multirow{2}{*}{$\begin{array}{c}\text { Disparitas } \\
\text { Gender }\end{array}$} \\
\hline & Jumlah & $\%$ & Jumlah & $\%$ & \\
\hline (1) & $(2)$ & (3) & $(4)$ & (5) & (6) \\
\hline $\begin{array}{l}\text { Mengikuti rapat menggali potensi } \\
\text { pariwisata }\end{array}$ & 48 & 24.0 & 34 & 17.0 & -7.0 \\
\hline $\begin{array}{l}\text { Mengikuti rapat pembangunan potensi } \\
\text { pariwisata }\end{array}$ & 52 & 26.0 & 37 & 18.5 & -8.0 \\
\hline $\begin{array}{l}\text { Mengikuti rapat pengembangan sarana } \\
\text { prasarana (sarpras) pariwisata }\end{array}$ & 57 & 28.5 & 33 & 16.5 & -12.0 \\
\hline $\begin{array}{l}\text { Mengikuti rapat pengembangan kegiatan } \\
\text { wisatawan di lokasi wisata }\end{array}$ & 56 & 28.0 & 34 & 17.0 & -11.0 \\
\hline $\begin{array}{l}\text { Mengikuti rapat sosialisasi pengembangan } \\
\text { pariwisata berwawasan lingkungan hidup }\end{array}$ & 40 & 20.0 & 33 & 16.5 & -3.5 \\
\hline $\begin{array}{l}\text { Mengikuti rapat sosialisasi Sapta Pesona } \\
\text { Pariwisata }\end{array}$ & 46 & 23.0 & 33 & 16.5 & -6.5 \\
\hline $\begin{array}{l}\text { Aktif mengeluarkan pendapat dalam } \\
\text { berbagai rapat }\end{array}$ & 45 & 22.5 & 28 & 14.0 & -8.5 \\
\hline Ikut dalam pengambilan keputusan & 31 & 15.5 & 24 & 12.0 & -3.5 \\
\hline
\end{tabular}

Sumber: data primer

Pada tahap implementasi pembangunan pariwisata ramah lingkungan, keterlibatan perempuan lebih tertinggal dibandingkan laki-laki, khususnya dalam aktivitas seperti pembangunan fisik, menyediakan jasa, mengambil keputusan dan pemeliharaan. Hasil studi ini menemukan bahwa ada pembagian peran gender dimana laki-laki lebih dominan dalam aktivitas-aktivitas seperti membangun sarana prasarana, membangun MCK (Mandi, Cuci, Kakus), menjaga keamanan dan menjaga ketertiban. Sebaliknya perempun dominan melakukan kegiatan menyediakan jasa boga di lokasi wisata, menata tempat dan barang dagangan serta menjaga toko dan melayani pembeli. Temuan ini memperkuat peran tradisional gender dimana laki-laki diidentikkan dengan kegiatan-kegiatan pembangunan fisik sedangkan perempuan dominan dalam menjalankan jasa pelayanan. Tabel 4 menggambarkan operasionalisasi dari keterlibatan perempuan dan laki-laki dalam tahap implementasi pembangunan pariwisata ramah lingkungan.

Tabel 4: Keterlibatan Tinggi Laki-laki dan Perempuan pada Tahap Implementasi

\begin{tabular}{|c|c|c|c|c|c|}
\hline \multirow{2}{*}{ Keterlibatan Tinggi Pada Tahap Implementasi } & \multicolumn{2}{|c|}{ Laki-laki } & \multicolumn{2}{|c|}{ Perempuan } & \multirow{2}{*}{$\begin{array}{c}\text { Disparitas } \\
\text { Gender }\end{array}$} \\
\hline & $\sum$ & $\%$ & $\sum$ & $\%$ & \\
\hline (1) & $(2)$ & (3) & $(4)$ & $(5)$ & (6) \\
\hline \multicolumn{6}{|l|}{ Pembangunan Fisik } \\
\hline * membangun sarana prasarana & 97 & 48.5 & 49 & 24.5 & -24.0 \\
\hline * membangun tempat berteduh (gazebo) & 51 & 25.5 & 28 & 14.0 & -11.5 \\
\hline * membangun MCK & 68 & 34.0 & 33 & 16.5 & -17.5 \\
\hline * menyediakan tempat sampah & 113 & 56.5 & 100 & 50.0 & -6.5 \\
\hline
\end{tabular}


Ismi Dwi Astuti Nurhaeni, Rara Sugiarti, Sri Marwanti, Ryza D. Pratiwi

\begin{tabular}{|c|c|c|c|c|c|c|}
\hline$\%$ & membuat papan informasi & 49 & 24.5 & 25 & 12.5 & -12.0 \\
\hline \multicolumn{7}{|c|}{ Menyediakan Jasa } \\
\hline$\%$ & jasa transportasi & 48 & 24.0 & 24 & 12.0 & -12.0 \\
\hline$\%$ & jasa komunikasi & 55 & 27.5 & 31 & 15.5 & -12.0 \\
\hline 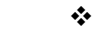 & jasa penginapan & 41 & 20.5 & 32 & 16.0 & -4.5 \\
\hline$*$ & jasa boga di lokasi wisata & 96 & 48.0 & 117 & 58.5 & 10.5 \\
\hline$\%$ & layanan kesehatan & 36 & 18.0 & 21 & 10.5 & -7.5 \\
\hline$\%$ & menjual tiket masuk & 28 & 14.0 & 5 & 2.50 & -11.5 \\
\hline$\%$ & menjual karcis parkir & 29 & 14.5 & 9 & 4.50 & -10.0 \\
\hline$\%$ & menjaga tempat parkir & 46 & 23.0 & 26 & 13.0 & -10.0 \\
\hline$\%$ & menjual suvenir & 57 & 28.5 & 62 & 31.0 & 2.5 \\
\hline$\$$ & menjaga keamanan & 146 & 73.0 & 100 & 50.0 & -23.0 \\
\hline$\%$ & melakukan penertiban sampah. & 133 & 66.5 & 117 & 58.5 & -8.0 \\
\hline$\%$ & menata tempat dan barang dagangan & 109 & 54.5 & 132 & 66.0 & 11.5 \\
\hline$\%$ & menjaga toko dan melayani pembeli & 99 & 49.5 & 135 & 67.5 & 18.0 \\
\hline \multicolumn{7}{|c|}{ Pengambilan Keputusan } \\
\hline$\%$ & ikut rapat evaluasi pelayanan wisata & 37 & 18.5 & 27 & 13.5 & -5.0 \\
\hline$\%$ & ikut rapat evaluasi keuangan & 38 & 19.0 & 29 & 14.5 & -4.5 \\
\hline \multicolumn{7}{|c|}{ Fungsi Pemeliharaan } \\
\hline 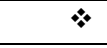 & menertibkan pedagang & 50 & 25.0 & 43 & 21.5 & -3.5 \\
\hline$\%$ & membersihkan tempat wisata & 146 & 73.0 & 138 & 69.0 & -4.0 \\
\hline$\%$ & menjaga keamanan & 154 & 77.0 & 114 & 57.0 & -20.0 \\
\hline$\%$ & menjaga ketertiban & 157 & 78.5 & 121 & 60.5 & -18.0 \\
\hline$\%$ & menjaga kebersihan & 165 & 82.5 & 160 & 80.0 & -2.5 \\
\hline$\%$ & menjaga kesejukan & 141 & 70.5 & 146 & 73.0 & 2.5 \\
\hline$*$ & menjaga keindahan & 151 & 75.5 & 157 & 78.5 & 3.0 \\
\hline$\%$ & ramah memberikan layanan wisata & 166 & 83.0 & 168 & 84.0 & 1.0 \\
\hline$\%$ & mewujudkan kenangan positif & 146 & 73.0 & 150 & 75.0 & 2.0 \\
\hline
\end{tabular}

Sumber: data primer

Pada tahap monitoring dan evaluasi pembangunan pariwisata ramah lingkungan, laki-laki dominan terlibat dalam aktivitas memantau kegiatan wisata dengan disparitas gender sebesar -11.5 dan memberikan saran perbaikan sarana dan layanan wisata dengan disparitas gender sebesar -8.0. Sebaliknya telah terjadi keadilan dan kesetaraan gender pada kegiatan menilai kegiatan wisata untuk perbaikan.

Tabel 5: Keterlibatan Tinggi Laki-laki dan Perempuan pada Tahap Monitoring dan Evaluasi

\begin{tabular}{|c|c|c|c|c|c|}
\hline \multirow{2}{*}{ Keterlibatan Tinggi pada Tahap Monitoring dan Evaluasi } & \multicolumn{2}{|c|}{ Laki-laki } & \multicolumn{2}{|c|}{ Perempuan } & \multirow{2}{*}{$\begin{array}{c}\text { Disparitas } \\
\text { Gender }\end{array}$} \\
\hline & $\sum$ & $\%$ & $\sum$ & $\%$ & \\
\hline$(1)$ & $(2)$ & (3) & $(4)$ & $(5)$ & $(6)$ \\
\hline Memantau kegiatan wisata & 72 & 36.0 & 49 & 24.5 & -11.5 \\
\hline Menilai kegiatan wisata untuk perbaikan & 50 & 25.0 & 46 & 23.0 & -2.0 \\
\hline Memberikan saran perbaikan sarana dan layanan wisata & 82 & 41.0 & 66 & 33.0 & -8.0 \\
\hline
\end{tabular}

Sumber: data primer 
Disparitas Gender Dalam Pembangunan Pariwisata ...

Rendahnya keterlibatan perempuan dibandingkan laki-laki dalam memberikan saran perbaikan disebabkan oleh adanya konstruksi sosial budaya bahwa mengemukakan pendapat dalam forum publik dipandang lebih cocok dilakukan oleh laki-laki daripada perempuan.

\section{Disparitas Gender Kompetensi Perempuan dan Laki-laki}

Kompetensi perempuan dalam pembangunan pariwisata ramah lingkungan dapat dilihat dari 10 indikator penilaian meliputi pemahaman tentang pariwisata, lingkungan hidup, pariwisata berwawasan lingkungan hidup, Sapta Pesona Pariwisata, penerapan prinsip pariwisata berwawasan lingkungan hidup, mendapat pelatihan tentang pariwisata berwawasan lingkungan hidup, menyetujui saran penggunaan bahan ramah lingkungan, melaksanakan pilah pilih sampah organik dan non organik, melakukan pengolahan sampah organik dan menggunakan bahan-bahan ramah lingkungan.

Hasil studi menemukan bahwa kompetensi perempuan dalam sebagian besar kegiatan pengembangan pariwisata ramah hidup lebih rendah dibandingkan laki-laki, terutama dalam hal memahami pariwisata dan memahami lingkungan hidup. Hanya ada tiga kompetensi perempuan yang lebih tinggi dibandingkan laki-laki, yaitu dalam hal menggunakan bahan-bahan ramah lingkungan, melakukan pengolahan sampah organik, setuju dan menyarankan penggunaan bahan ramah lingkungan. Sedangkan kesetaraan dan keadilan gender sudah terjadi dalam hal mendapatkan pelatihan pariwisata ramah lingkungan dan melaksanakan pilah pilih sampah organik dan non organik.

Tabel 6: Kompetensi Tinggi Perempuan dan Laki-laki dalam Pembangunan Pariwisata Ramah Lingkungan

\begin{tabular}{|c|c|c|c|c|c|}
\hline \multirow{2}{*}{ Kompetensi Tinggi } & \multicolumn{2}{|c|}{ Laki-laki } & \multicolumn{2}{|c|}{ Perempuan } & \multirow{2}{*}{$\begin{array}{l}\text { Disparitas } \\
\text { Gender }\end{array}$} \\
\hline & Total & $\%$ & Total & $\%$ & \\
\hline (1) & (2) & (3) & (4) & (5) & (6) \\
\hline Memahami pariwisata & 163 & 81.5 & 142 & 71.0 & -10.5 \\
\hline Memahami pariwisata berwawasan lingkungan hidup & 71 & 35.5 & 64 & 32.0 & -3.5 \\
\hline Memahami Sapta Pesona Pariwisata & 71 & 35.5 & 60 & 30.0 & -5.5 \\
\hline Menggunakan bahan-bahan ramah lingkungan & 123 & 61.5 & 141 & 70.5 & 9.0 \\
\hline $\begin{array}{l}\text { Setuju dan menyarankan penggunaan bahan ramah } \\
\text { lingkungan }\end{array}$ & 53 & 26.5 & 71 & 35.5 & 9.0 \\
\hline Melaksanakan pilah pilih sampah organik dan non organik & 36 & 18.0 & 42 & 21.0 & 3.0 \\
\hline Melakukan pengolahan sampah organik & 156 & 78.0 & 173 & 86.5 & 8.5 \\
\hline
\end{tabular}




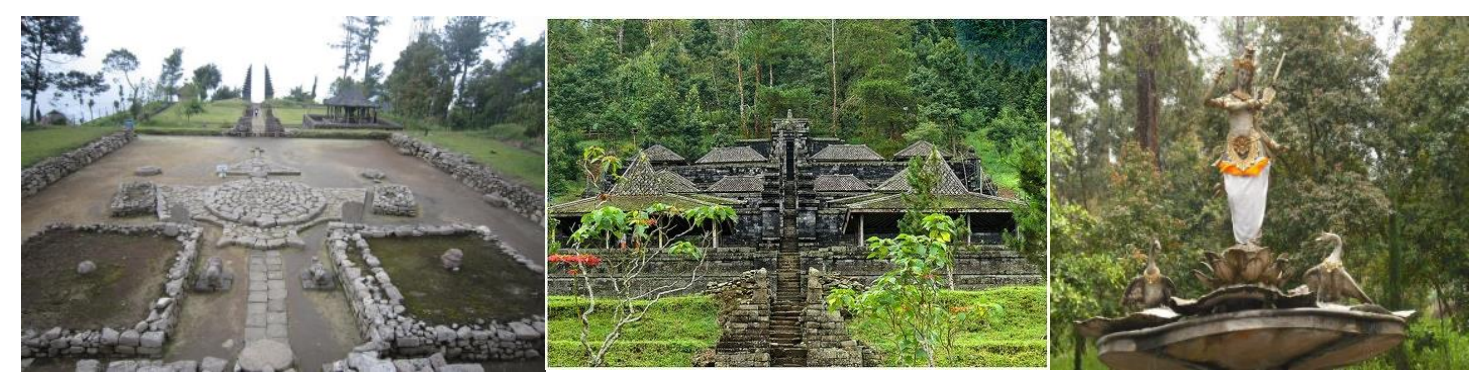

Gambar 1: Lokasi Wisata di Kecamatan Jenawi

Jika di lihat menurut lokasi wisata, kompetensi laki-laki lebih tinggi dibandingkan perempuan di Kecamatan Jenawi (17.5\% berbanding $10.0 \%)$ dan di Kecamatan Ngargoyoso (laki-laki 50.0\% berbanding perempuan 32.5\%). Sementara itu kompetensi perempuan lebih tinggi dibandingkan laki-laki di Kecamatan Karangpandan (52.5\% berbanding 43.5\%), Kecamatan Matesih (37.5\% berbanding 32.5\%), Kecamatan Tawangmangu (47.5\% berbanding $35.0 \%$ ). Lebih tingginya kompetensi masing-masing jenis kelamin di setiap lokasi pariwisata diduga terkait dengan jenis pariwisata yang dikembangkan. Di Kecamatan Jenawi, pariwisata andalan yang dikembangkan adalah wisata peninggalan sejarah dan wisata alam. Wisata peninggalan sejarah berupa Candi Cetho (sebuah candi yang berlatar belakang kepercayaan agama Hindu) dan patung Dewi Saraswati, yang langsung didatangkan dari Bali. Wisata sejarah ini lebih banyak dikunjungi oleh orang-orang yang akan melakukan kegiatan spiritual. Sedangkan wisata alam di Kecamatan Jenawi berupa hamparan perkebunan teh yang dikelola oleh PT. Rumpun Sari Kemuning dan air terjun Temanten di Desa Gumeng.

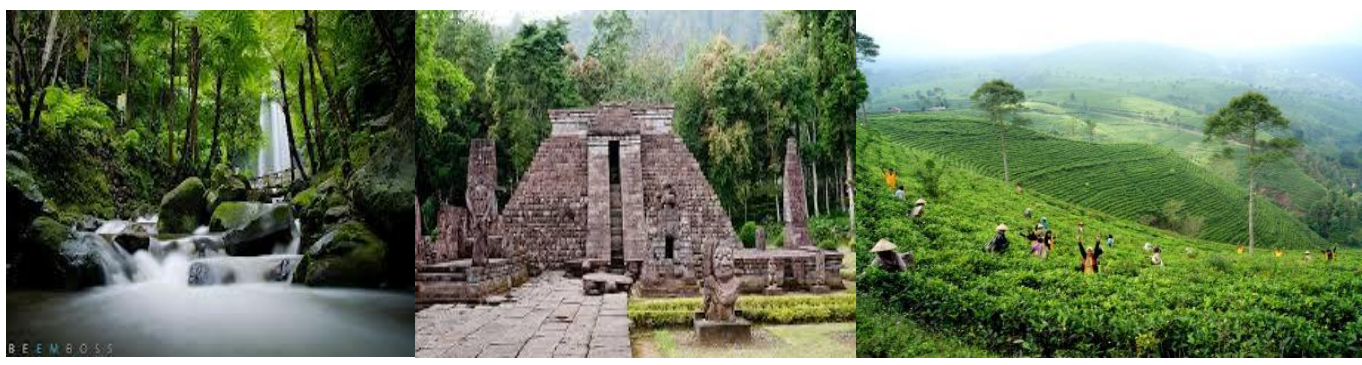

Gambar 2: Tempat Pariwisata di Ngargoyoso

Di wilayah Kecamatan Ngargoyoso terdapat banyak daya tarik wisata, baik daya tarik wisata alam (seperti air terjun Jumog, perkebunan teh Kemuning, Telaga Madirdo, Taman Hutan Raya), wisata budaya (Candi Sukuh), maupun buatan (kolam renang). Air Terjun Jumog merupakan air terjun dengan ketinggian sekitar 30 meter. Konon, setiap pukul sepuluh pagi, muncul pelangi 
Disparitas Gender Dalam Pembangunan Pariwisata ...

di air terjun ini. Lokasinya berada di Desa Berjo yang telah dicanangkan sebagai desa wisata oleh Pemerintah Kabupaten Karanganyar. Tidak terlalu jauh dari air terjun Jumog terdapat Candi Sukuh yang dikenal sebagai candi erotis karena pada candi tersebut terdapat banyak ornamen erotis. Candi Sukuh memiliki keunikan dengan bangunan mirip piramid Suku Maya di Amerika Tengah. Kompleks candi Sukuh tidak begitu luas. Menempati sebidang tanah berundak, gapura utama Sukuh tidak berada tepat di tengah melainkan di sebelah kanan depan. Sisi kanan dan kiri dihiasi dengan beberapa relief. Salah satunya adalah gambar seekor burung Garuda yang kaki-kakinya mencengkeram seekor naga. Yang mengherankan adalah adanya relief beberapa sosok manusia dalam keadaan polos, tanpa busana sama sekali. Sesuatu yang cukup mencengangkan jika mengingat budaya timur yang sangat kental dengan norma susila di Indonesia. Ditambah lagi bila mengingat bahwa ini adalah candi, sebuah bangunan yang identik sebagai tempat persembahyangan dan pemujaan dewa. Di candi utama di teras ketiga, berdiri sebuah panggung batu setinggi pinggang orang dewasa di sebelah kirinya. Terdapat menara batu di bagian depan panggung, berhiaskan relief-relief erotis dari sosok-sosok tanpa busana. Selain candi Sukuh, juga terdapat perkebunan teh yang luas membentang di wilayah Kecamatan Ngargoyoso yang dikelola oleh PT Rumpun Sari Kemuning. Suasana di perkebunan teh ini amat nyaman dengan hawa udara yang sejuk sehingga membuat para pengunjung betah untuk berlama-lama menyaksikan lukisan alam berupa hamparan pohon-pohon teh yang tumbuh dengan subur di bawah lereng Gunung Lawu. Perkebunan ini menawarkan banyak hal yang menarik, mulai dari pemandangan yang asri dan alami serta udara yang sejuk, bersih, dan segar.

Kompetensi perempuan lebih tinggi dibandingkan laki-laki dalam pengembangan pariwisata di Kecamatan Karangpandan, Kecamatan Matesih dan Kecamatan Tawangmangu. Di wilayah Kecamatan Karangpandan dikembangkan daya tarik wisata berupa Sub Terminal Agribisnis yang terletak di jalan raya menuju Tawangmangu, tepatnya di perempatan Karangpandan. Di lokasi tersebut dikembangkan berbagai jenis tanaman, baik tanaman hias, sayur/hortikultura maupun tanaman biofarmaka untuk obat keluarga. 


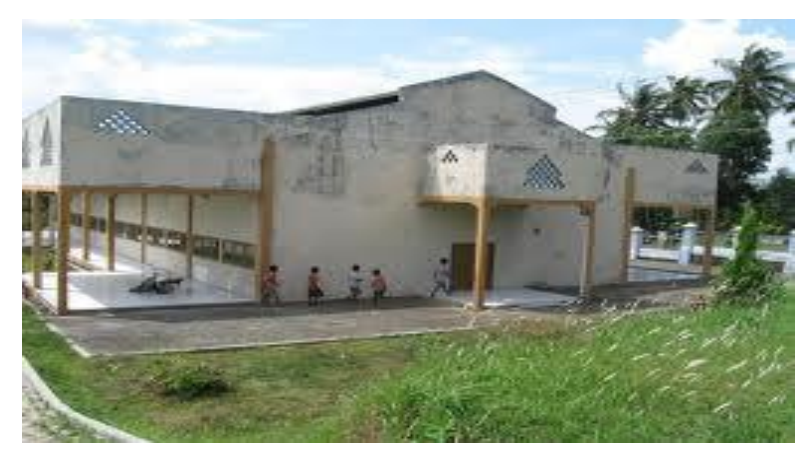

Gambar 3: Sub Terminal Agribisnis di Karangpandan

Kecamatan Matesih terdapat wisata peninggalan sejarah dan wisata spiritual. Wisata peninggalan sejarah berupa Sapta Tirta Pablengan merupakan salah satu keajaiban alam di bumi Indonesia berupa tujuh mata air. Uniknya, tujuh mata air tersebut berkumpul di satu areal dengan luas sekitar 2 (dua) hektar. Jarak satu mata air dengan mata air yang lain, paling dekat kurang lebih 5 (lima) meter, paling jauh kira-kira 15 meter. Ke-7 mata air tersebut mengeluarkan air dengan kandungan mineral yang berbeda. Wisata spiritual yang sangat terkenal adalah Astana Giribangun (tempat Presiden Soeharto dan istrinya, Ibu Tien Soeharto, dimakamkan), serta Astana Girilayu dan Astana Mangadeg (keduanya merupakan tempat dimakamkannya raja-raja dari keluarga Pura Mangkunegaran Solo).

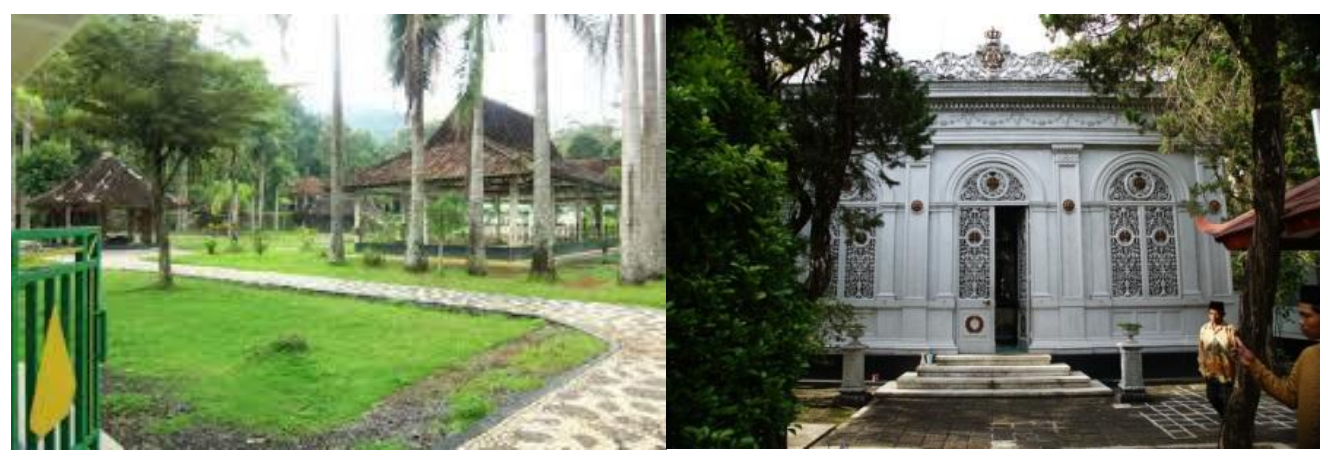

Gambar 4: Tempat Wisata di Matesih

Di wilayah Kecamatan Tawangmangu, terdapat banyak daya tarik wisata, baik daya tarik wisata alam (air terjun Grojogan Sewu, budaya (upacara adat Mondosiyo), maupun buatan (Bumi Perkemahan Sekipan dan Taman Balekambang). Grojogan Sewu berarti air terjun seribu. Kata sewu atau seribu berasal dari seribu pecak, atau satuan jarak untuk mengukur tinggi air terjun. Satu pecak sama dengan satu telapak kaki orang dewasa. Ketinggian air terjun Grojogan Sewu adalah sekitar 80 meter. Di kawasan ini terdapat Hutan Wisata Grojogan Sewu seluas 20 Ha. Kawasan hutan ini banyak ditumbuhi berbagai 
Disparitas Gender Dalam Pembangunan Pariwisata ...

jenis pohon hutan dan dihuni oleh sekelompok kera jinak. Beberapa fasilitas dari hutan wisata ini adalah Taman Binatang Hutan, kolam renang, tempat istirahat, kios makanan, kios buah-buahan dan cinderamata, mushola dan MCK (Mandi, Cuci dan Kakus). Di wilayah Kecamatan Tawangmangu juga terdapat Taman Ria Balekambang sebagai arena rekreasi keluarga dengan menyajikan berbagai tempat bermain untuk anak-anak seperti jungkat-jungkit, ayunan, "perosotan", becak-becakan dan mainan-mainan lain yang cocok bagi anak umur di atas 3 (tiga)tahun, serta tempat pertemuan. Di Tawangmangu juga terdapat bumi perkemahan, salah satunya adalah Bumi Perkemahan Sekipan. Lokasi bumi perkemahan ini berada di suatu lembah yang dikelilingi bukit dengan udara yang sejuk dan hawa yang bersih dan segar. Di dekat bumi perkemahan terdapat rumah penduduk yang difungsikan sebagai homestay serta ladang penduduk yang ditanami dengan strawberry dan tanaman sayuran.

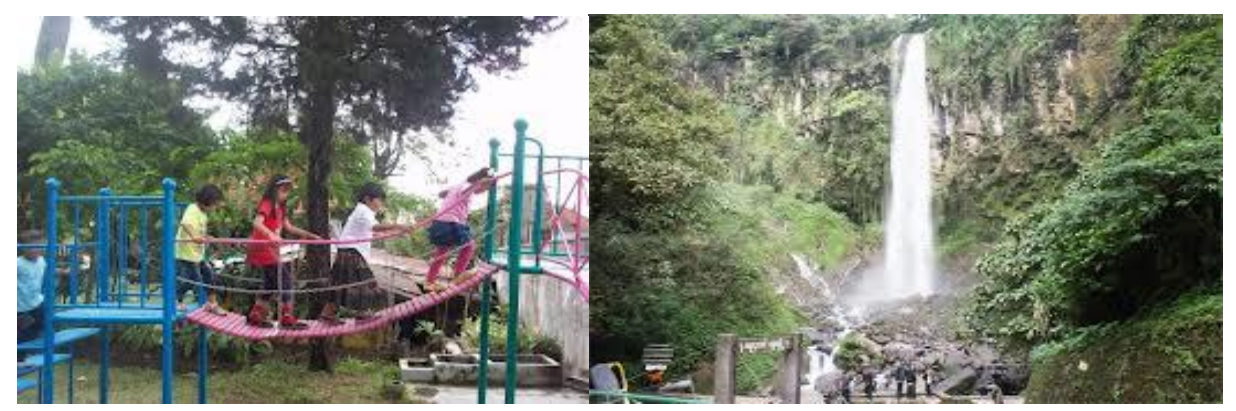

Gambar 5: Tempat Wisata di Tawangmangu

\section{Disparitas Gender Hambatan Internal dan Eksternal Perempuan dan Laki-laki}

Perempuan memiliki hambatan internal yang lebih tinggi dibandingkan laki-laki dalam pembangunan pariwisata dengan perbandingan $51.5 \%$ berbanding $43.5 \%$ dengan disparitas gender sebesar -8. Hambatan-hambatan tersebut terutama adalah terbatasnya pengetahuan perempuan mengenai pariwisata, terbatasnya pengetahuan perempuan mengenai lingkungan hidup, terbatasnya keterampilan perempuan melakukan pekerjaan di bidang pariwisata dan rendahnya tingkat pendidikan perempuan. Pada sisi lain sebenarnya perempuan memiliki antusiasme yang sama baiknya dengan lakilaki di bidang pariwisata serta sama-sama kurang memiliki kreativitas dalam menangkap peluang pekerjaan di bidang pariwisata. 
Ismi Dwi Astuti Nurhaeni, Rara Sugiarti, Sri Marwanti, Ryza D. Pratiwi

Tabel 7: Hambatan Internal dalam Pengembangan Pariwisata Ramah Lingkungan Menurut Jenis Kelamin

\begin{tabular}{|c|c|c|c|c|c|}
\hline \multirow{2}{*}{ Hambatan Internal Tinggi } & \multicolumn{2}{|c|}{ Laki-laki } & \multicolumn{2}{|c|}{ Perempuan } & \multirow{2}{*}{$\begin{array}{c}\text { Disparitas } \\
\text { Gender }\end{array}$} \\
\hline & Jumlah & $\%$ & Jumlah & $\%$ & \\
\hline (1) & $(2)$ & (3) & $(4)$ & (5) & (6) \\
\hline Terbatasnya pengetahuan mengenai pariwisata & 89 & 44.5 & 107 & 53.5 & 9.0 \\
\hline Terbatasnya pengetahuan mengenai lingkungan hidup & 88 & 44.0 & 110 & 55.0 & 11.0 \\
\hline Terbatasnya keterampilan kerja di bidang pariwisata & 78 & 39.0 & 99 & 49.5 & 10.5 \\
\hline Rendahnya tingkat pendidikan & 105 & 52.5 & 127 & 63.5 & 11.0 \\
\hline Kurangnya antusiasme bekerja di bidang pariwisata & 93 & 46.5 & 92 & 46.0 & -0.5 \\
\hline Kurangnya motivasi bekerja di bidang pariwisata & 104 & 52.0 & 95 & 47.5 & -4.5 \\
\hline $\begin{array}{l}\text { Kurangnya kreativitas menangkap peluang kerja } \\
\text { pariwisata }\end{array}$ & 108 & 54.0 & 110 & 55.0 & 1.0 \\
\hline Rendahnya pendapatan bekerja di bidang pariwisata & 97 & 48.5 & 103 & 51.5 & 3.0 \\
\hline
\end{tabular}

Sumber: data Primer

Hambatan eksternal dalam pembangunan pariwisata ramah lingkungan dirasakan oleh laki-laki maupun perempuan dengan perbandingan $72.5 \%$ berbanding $71.0 \%$. Berdasarkan hasil penelitian ditemukan bahwa perbedaan utama hambatan eksternal dalam pengembangan pariwisata ramah lingkungan antara laki-laki dan perempuan adalah dalam hal belum ada kebijakan khusus pengembangan pariwisata ramah lingkungan.

Hambatan eksternal dalam pengembangan pariwisata ramah lingkungan dapat dilihat dari 4 (empat) aspek penilaian, meliputi: (a) belum adanya kebijakan khusus untuk mengembangkan pariwisata berwawasan lingkungan hidup; (b) belum adanya kebijakan khusus untuk pemberdayaan perempuan dalam pengembangan pariwisata berwawasan lingkungan hidup; (c) terbatasnya kegiatan pemberdayaan perempuan di bidang pariwisata; dan (d) terbatasnya anggaran untuk kegiatan pemberdayaan perempuan di bidang pariwisata.

Tabel 8. Hambatan Eksternal dalam Pengembangan Pariwisata Ramah Lingkungan Menurut Jenis Kelamin

\begin{tabular}{|c|c|c|c|c|c|}
\hline \multirow{2}{*}{ Hambatan Eksternal Tinggi } & \multicolumn{2}{|c|}{ Laki-laki } & \multicolumn{2}{|c|}{ Perempuan } & \multirow{2}{*}{$\begin{array}{l}\text { Disparitas } \\
\text { Gender }\end{array}$} \\
\hline & Jumlah & $\%$ & Jumlah & $\%$ & \\
\hline$(1)$ & $(2)$ & (3) & $(4)$ & (5) & (6) \\
\hline $\begin{array}{l}\text { Belum ada kebijakan khusus pengembangan } \\
\text { pariwisata ramah lingkungan }\end{array}$ & 144 & 72.0 & 133 & 66.5 & -5.5 \\
\hline $\begin{array}{l}\text { Belum ada kebijakan khusus pemberdayaan } \\
\text { perempuan dalam pengembangan pariwisata ramah } \\
\text { lingkungan }\end{array}$ & 158 & 79.0 & 157 & 78.5 & -0.5 \\
\hline $\begin{array}{l}\text { Terbatasnya kegiatan pemberdayaan perempuan di } \\
\text { bidang pariwisata }\end{array}$ & 155 & 77.5 & 156 & 78.0 & 0.5 \\
\hline $\begin{array}{l}\text { Terbatasnya anggaran untuk kegiatan } \\
\text { pemberdayaan perempuan di bidang pariwisata }\end{array}$ & 150 & 75.0 & 158 & 79.0 & 4.0 \\
\hline
\end{tabular}

Sumber: data primer 


\section{Diskusi}

\section{a. Stereotip Gender Menyebabkan Dominasi Laki-laki}

Stereotip gender (yaitu perempuan melakukan pekerjaan domestik dan laki-laki melakukan pekerjaan publik) menyebabkan terjadinya dominasi lakilaki dan marginalisasi perempuan dalam perencanaan, implementasi, monitoring dan evaluasi pembangunan pariwisata ramah lingkungan. Selain itu, anggapan bahwa perempuan itu lemah dan tergantung telah menghalangi kesempatan perempuan untuk menyuarakan pendapat mereka dalam forumforum publik dan berpartisipasi dalam pengembangan fasilitas, infra struktur dan jumlah wisatawan. Temuan ini memperkuat peran gender tradisional yang menyatakan bahwa laki-laki lebih cocok melakukan kegiatan pembangunan fisik, sementara perempuan lebih cocok melakukan kegiatan domestik. Dikotomi peran gender dalam pengembangan pariwisata ramah lingkungan ini dipengaruhi oleh budaya patriarki yang cenderung memarginalkan perempuan. Hal ini sejalan dengan pemikiran eco-feminist yang memandang adanya hubungan antara alam, perempuan, budaya patriarki dan kapitalis. Hubungan antara perempuan dengan eksploitasi alam dikontrol oleh kepentingan kapitalis dan patriarki. Untuk mengatasi hubungan yang eksploitatif diperlukan pemahaman tentang perspektif ekologi dan feminis (d'Eabonne dalam Subono, 2014; Shiva \& Mies, 2005).

Shiva \& Mies (2005:79) mengemukakan bahwa "pembangunan yang mestinya menciptakan kesejahteraan dan kemakmuran bagi semua masyarakat di Dunia Ketiga ternyata justru menyebabkan terjadinya degradasi lingkungan dan kemiskinan. Semakin meningkatnya keterbelakangan perempuan bukan lantaran mereka tidak layak dan tidak mampu berpartisipasi dalam pembangunan, tetapi karena perlakuan yang tidak adil dan kerja yang mereka lakukan tidak dianggap sebagai kerja yang menghasilkan keuntungan.

Shiva \& Mies (2005: 79-85) menyatakan bahwa kontribusi perempuan dalam pembangunan diabaikan karena: (1) pekerjaan perempuan diasosiasikan dengan proses natural (alamiah); (2) pekerjaan perempuan dilakukan untuk mmenuhi kebutuhan dasar dan menjamin kebutuhan untuk hidup; (3) pekerjaan ini tidak dipertimbangkan berkontribusi terhadap penerimaan Gross National Product (GNP) dan tidak dijadikan sebagai indikator pembangunan.

Upaya untuk meningkatkan keterlibatan perempuan dalam pembangunan pariwisata ramah lingkungan dapat dilakukan melalui peran asosiasi kelompok swadaya yang memungkinkan perempuan untuk mendapatkan kontrol lebih besar atas 
sumber daya seperti kepemilikan materi, sumber daya intelektual seperti pengetahuan, informasi, ide dan pengambilan keputusan di rumah, masyarakat, maupun bangsa. Hal ini sesuai dengan hasil penelitian Suja (2012) dalam penelitiannya di Tamil Nadu tahun 2012 yang menyatakan bahwa asosiasi tersebut memiliki perhatian pada peningkatan keterampilan, memfasilitasi penemuan baru, memperoleh akses ke kredit dari lembaga keuangan untuk usaha mikro, menanamkan hidup hemat dan pengawasan kredit untuk perempuan miskin. Menurutnya, perempuan dapat mencapai kekuasaan, jika dia memiliki status layak secara finansial, sosial dan budaya. Hal itulah yang disebut pemberdayaan. Lebih lanjut diungkapkan oleh Radel (2012) bahwa aliansi cukup berhasil dalam memenuhi kepentingan konservasi, memberikan kontribusi terhadap mata pencaharian perempuan, dan meningkatkan posisi relatif mereka dalam rumah tangga dan masyarakat melalui perubahan dalam kontrol gender pengambilan keputusan sumber daya.

Di basis lokal, terdapat asosiasi kelompok bernama Lembaga Masyarakat Desa Hutan (LMDH). Lembaga ini sudah berjalan tanpa adanya representasi perempuan. Karena itu perlu adanya reformasi struktural pada kelembagaan LMDH dengan representasi perempuan minimal 30\%. Dengan reformasi ini perempuan mempunyai peluang untuk menyuarakan aspirasinya, serta berpartisipasi aktif dalam pengembangan pariwisata ramah lingkungan. Hal penting yang harus dilakukan adalah melakukan pemberdayaan perempuan. Menurut United States Agency for International Development (2013), pemberdayaan mengacu kepada proses peningkatan kesempatan bagi orang-orang untuk mengontrol kehidupannya sendiri. Hal ini berkaitan dengan adanya keinginan manusia untuk hidup sesuai dengan nilai mereka sendiri dan mampu mengekspresikan preferensi, membuat pilihan yang berpengaruh terhadap kehidupannya, baik secara individu maupun secara kolektif. Pemberdayaan perempuan atau laki-laki mencakup pengembangan kemandirian, mendapatkan keterampilan atau memiliki keterampilan dan pengetahuan mereka sendiri yang diakui, dan meningkatkan kekuatan mereka untuk membuat keputusan dan mendengar suara mereka, dan untuk menegosiasikan dan menantang norma dan kebiasaan masyarakat. Alsop, Bertelsen \& Holland (2006:1) menyatakan bahwa pemberdayaan didefinisikan sebagai "proses untuk meningkatkan kemampuan seseorang atau kelompok untuk membuat pilihan secara purposif dan mengubah pilihan tersebut menjadi tindakan dan hasil yang diinginkan." Dengan menggunakan konsep struktur peluang berbasis lembaga berbasis aset dan institusi, kerangka kerja yang disajikan menunjukkan bahwa investasi dan intervensi dapat memberdayakan masyarakat dengan memusatkan perhatian 
Disparitas Gender Dalam Pembangunan Pariwisata ...

pada hubungan dinamis dan interaktif antara lembaga dan struktur. Singkatnya, intervensi untuk memperbaiki lembaga dan meningkatkan struktur kesempatan dapat meningkatkan kapasitas masyarakat untuk membuat pilihan yang efektif, dan pada gilirannya dapat menghasilkan hasil pembangunan lainnya (Alsop, Bertelsen \& Holland, 2006:1).

World Bank (2002: vi-vii) menyatakan pemberdayaan mengacu secara luas pada perluasan kebebasan memilih dan bertindak. Keempat elemen kunci pemberdayaan yang harus mendasari reformasi kelembagaan adalah: (1) Akses terhadap informasi; (2) Inklusi/partisipasi; (3) Akuntabilitas; (4) Kapasitas organisasi lokal. Menurut World Bank (2002) akses terhadap informasi itu merupakan kekuatan. Warga yang memiliki akses terhadap informasi lebih siap untuk memanfaatkan kesempatan, layanan akses, menjalankan hak mereka, dan meminta pertanggungjawaban aktor negara dan non-negara. Sementara itu, adanya inklusi/partisipasi berarti memberi kesempatan bagi orang miskin dan kelompok lain (termasuk perempuan dan laki-laki) yang tidak diikutsertakan untuk berpartisipasi dalam pengambilan keputusan sehingga mereka dapat memastikan bahwa penggunaan sumber daya publik yang terbatas dapat terdistribusi dengan tepat. Namun, mempertahankan inklusi/partisipasi dan informasi biasanya memerlukan perubahan peraturan sehingga dapat menciptakan ruang bagi masyarakat untuk memperdebatkan isu dan berpartisipasi dalam penetapan prioritas lokal dan nasional, pembentukan anggaran, dan penyampaian layanan dasar. Selain itu, akuntabilitas dari pejabat negara, pegawai negeri, dan pelaku swasta atas kebijakan, tindakan, dan penggunaan dana harus dilaksanakan, baik melalui mekanisme pertanggungjawaban horizontal atau internal, maupun bertanggung jawab kepada warga dan klien atas kinerjanya. Pada akhirnya, dengan kapasitas organisasi lokal dimaksudkan agar mereka memiliki kemampuan untuk bekerja sama, mengatur diri mereka sendiri, dan memobilisasi sumber daya untuk memecahkan masalah yang menjadi kepentingan bersama. Dengan pemberdayaan perempuan serta pemberian ruang partisipasi di tingkat kelembagaan lokal (LMDH) diharapkan dapat meningkatkan kapasitas perempuan dalam pengambilan keputusan.

\section{b. Perempuan Sebagai Pendidik Lingkungan}

Perempuan telah menjalankan peran pemeliharaan dalam pengelolaan pariwisata ramah lingkungan, terutama melalui fungsi sebagai edukator lingkungan bagi keluarga dan masyarakat. Peran ini dijalankan tanpa tercerabut dari nilai-nilai sosial budaya setempat karena perempuan telah menyatu dengan 
alam. Peran ini merupakan kunci strategis untuk menjaga dan memelihara kualitas lingkungan dalam pengembangan pariwisata, sehingga pariwisata yang ada tidak hanya memenuhi prinsip ekonomi semata, tetapi juga memenuhi prinsip ekologi dan sosial budaya. Karena itu, optimalisasi kualitas feminin dan peran keibuan yang sangat peduli terhadap kerusakan lingkungan hidup harus terus dibangkitkan dan dipelihara dalam pengembangan pariwisata ramah lingkungan, karena menghilangnya kualitas pengasuhan dan pemeliharaan (kualitas feminin) akan berakibat kepada adanya dominasi sistem maskulin yang berpotensi menimbulkan kerusakan alam dan degradasi moral. Perempuan tidak perlu mengadopsi kualitas maskulin agar pengelolaan lingkungan tidak berstruktur maskulin yang identik dengan penindasan.

Selain sebagai edukator, perempuan memainkan peran pentingnya dalam berbagai lobi untuk mendesakkan lahirnya kebijakan pembangunan responsif gender. Hal ini ditunjukkan dari hasil riset Buckingham (2004) yang menemukan adanya pengaruh ecofeminism terhadap kebijakan yang berkaitan dengan ketidaksetaraan gender dan lingkungan. Hasil risetnya menemukan adanya pergeseran kebijakan yang substansial di Eropa dan UK sebagai akibat dari lobi-lobi yang dilakukan oleh ecofeminism.

Hasil riset ini sejalan dengan temuan Hunte, Hatch \& Johnson (2004) yang menyatakan "di berbagai Negara, perempuan lebih terikat dengan perilaku ramah lingkungan dibandingkan laki-laki, khususnya perilaku privat. Sementara itu, baik laki-laki maupun perempuan cenderung terikat dengan perilaku ramah lingkungan di sektor privat daripada sektor publik. Hasil studi ini bertentangan dengan temuan lainnya yang menyatakan bahwa "perempuan kurang sadar terhadap isu-isu lingkungan dibandingkan laki-laki. Di Negara Barat, laki-laki menunjukkan lebih peduli dan punya pandangan yang lebih positif untuk membeli barang-barang yang ramah lingkungan dibandingkan perempuan.

\section{Simpulan}

Terdapat disparitas gender dalam pengembangan pariwisata ramah lingkungan hidup di kawasan Gunung Lawu Karanganyar Indonesia, dimana perempuan cenderung masih termarginalkan baik dalam hal keterlibatan, kompetensi, hambatan internal maupun hambatan eksternal. Disparitas gender tertinggi dalam keterlibatan perempuan dan laki-laki pada pembangunan pariwisata ramah lingkungan terjadi pada tahap implementasi dibandingkan pada tahap perencanaan, monitoring serta evaluasi. 
Hasil penelitian juga menemukan adanya disparitas gender dalam kompetensi, dimana kompetensi perempuan lebih rendah dibandingkan lakilaki. Selain itu, disparitas gender juga terjadi dalam hambatan internal dan eksternal, dimana perempuan memiliki hambatan internal dan eksternal yang lebih tinggi dibandingkan laki-laki. Rekomendasi penelitian adalah perlunya percepatan pengarusutamaan gender dalam pengembangan pariwisata ramah lingkungan melalui alokasi anggaran responsif gender dengan perhatian utama mengatasi stereotip gender dan peningkatan kapasitas sumber daya manusia dalam pengembangan pariwisata ramah lingkungan. 


\section{DAFTAR PUSTAKA}

Alsop, R; Bertelsen, M.F. \& Holland, J., 2006, Empowerment in Practice: From Analysis to Implementation, Washington USA: The International Bank for Reconstruction and Development/ The World Bank.

Buckingham, S., 2004, "Ecofeminism in the twenty-first century" dalam Geographical Journal. Vol. 170 No. 2 p 146-164

Clements, S., 2007, A Resource guide for Sustainable Tourism, Down East Resource Conservation and Development Council: Sea Grant Publication.

Farsari, Y \& Prastacos, $\mathrm{P}, \mathrm{tt}$, Sustainable tourism indicator for mediterranian established destinations. Greece: Foundation for the research and the Technology Hellas (FORTH).

Ghimire, S. \& Upreti, B. R., 2011, “Community participation for environmentfriendly toruism: the avenue for local peace". The Journal for Tourism and Peace Research. Vol. 2 No.1 pp 55-69.

Hunter, L.M., Hatch, A. \& Johnson, A., 2004, “Cross-National Gender Variation in Environmental Behaviors". Social Science Quarterly (Wiley-Blackwell), Vol. 85 Issue 3, p677-694.

Kelkit, A; Celik, S; Esbah, H., 2010, "Ecotourism Potential of Gallipoli Peninsula Historical National Park". Journal of Coastal Research, Vol. 26 Issue 3, p562-568.

Khotimah, N., 2005, "Potensi Kecamatan Imogiri Kabupaten Bantul untuk Pengembangan Pariwisata Berwawasan Lingkungan", Yogyakarta: Universitas Gadjah Mada (Tesis). (http:/ / etd.ugm.ac.id/index.php?mod=penelitian_detail\&sub=Penelitian Detail\&act=view\&typ=html\&buku_id=27538\&obyek_id=4).

Merce, I.I.; Milin. I. A., 2014, "Ecotourism Destinations in Romania", Scientific Papers: Animal Science \& Biotechnologie, Vol. 47 Issue 1, p327-329.

Nugroho, P. S., 2012, “Pengelolaan Kawasan Wisata Berbasis Masyarakat sebagai upaya Penguatan Ekonomi Lokal dan Pelestarian Sumber Daya Alam di Kabupaten Karanganyar", Surakarta: Universitas Sebelas Maret (Laporan Penelitian).

Pamulardi, B., 2006, "Pengembangan Agrowisata Berwawasan Lingkungan: Studi Kasus di Desa Tingkir Salatiga", Semarang: Universitas Diponegoro.

Radel, C. A., 2012, "Outcomes of Conservation Alliances with Women's Community-Based Organizations in Southern Mexico", Society \& Natural Resources, Vol. 25 Issue 1, p52-70. 
Disparitas Gender Dalam Pembangunan Pariwisata ...

Shiva, Vandana. 'Pemiskinan terhadap Lingkungan: Perempuan dan Anak yang Jadi Korban”. Dalam Shiva, V. dan Mies, M., 2005, Ecofeminism: Perspektif Gerakan Perempuan dan Lingkungan. Yogyakart: IRE Press.

Silva, J. A dan Khatiwada, L.K. 2014. “Transforming Conservation into Cash?”. Nature Tourism in Southern Africa. Africa Today. Vol. 61 Issue 1, p17-45.

Subono, N. I. 2014. “Kata dan Makna”. dalam Jurnal Perempuan Vol. 19 No. 1.

Suja, S., 2012, "Women Empowerment Through Self-Help Group- An Evaluative Study", Global Management Review, Vol. 6 Issue 3, p68-82.

Tong, R. P., 1998, Feminist Though: A More Comphrehensive Introduction (second edition), Colorado: Westview Press.

USAID, 2013, Women's Empowerment in Agriculture Assessment Indonesia 2013, USA: Weidemann Associates, Inc.

Utami, E, 2000, Strategi Pengembangan Pariwisata Tirta Berwawasan Lingkungan: Studi Kasus di Waduk Cirata Kabupaten Cianjur Jawa Barat, http:/ / repository.ipb.ac.id/bitstream/handle/ 123456789/23982/C00EUT.pdf?sequence $=2$

World Bank. 2002. Empowerment and Poverty Reduction: A Sourcebook.

Wearing, S. L.; Cunningham, P.A.; Schweinsberg, S. \& Jobberns, C., 2014, “Whale Watching as Ecotourism: How Sustainable is it?", Cosmopolitan Civil Societies: An Interdisciplinary Journal, Vol. 6 Issue 1, p38-55.

\section{Peraturan-Peraturan:}

Beijing Declaration and Platform for Actiondalam http:/ / www.lbh-apik.or.id/fac25.htm.

Instruksi Presiden Nomor 9 Tahun 2000 tentang Pengarusutamaan Gender Dalam Pembangunan Nasional.

Peraturan Menteri dalam Negeri Nomor 67 Tahun 2011 Tentang Perubahan atas Peraturan Menteri dalam Negeri Nomor 15 Tahun 2008 Tentang Pedoman Pelaksanaan Pengarusutamaan Gender di Daerah.

Presidential Decree No. 5 Year 2010

Undang-Undang Republik Indonesia Nomor 10 Tahun 2009 Tentang Kepariwisataan.

UU No 7/ 1984 Tentang Ratifikasi Konvensi Penghapusan Segala Bentuk Diskriminasi Terhadap Perempuan 